\title{
The Case for Prophecy: Politics, Gender and Self-representation in 17th-Century Prophetic Discourses
}

\author{
Carme Font Paz \\ Autonomous University of Barcelona \\ carme.font@uab.cat
}

\begin{abstract}
$\mathrm{R}$ It has been suggested that women prophets in the culture of seventeenth-century England represent the first significant group of women to establish the political authority of self-conscious female identity, and that as such they stand for a foundational moment in the development of modern feminist consciousness.

This article argues that the political, religious and social upheavals in the English Revolution witnessed an unprecedented outburst of prophetic speech among women. As a result, women prophets forged a widely-read and persuasive literary genre which suited both their private and public concerns; at the same time, this venue allowed them to approach a sense of feminine writing away from the topos found in the Querelles des femmes, thus contributing to the formation of a prehistory of novelistic discourse.

Focusing on the persuasive narrative of Lady Eleanor Davies, this article shows how prophetesses used a deeply personal rhetorical discourse which appropriates the voice and the manner of the Hebrew prophets of old. Many female visionaries understood themselves to be called by God to warn political leaders, and calls to prophesy and to intervention in the public sphere could take the form of anagrams, dramatic visions, complex dreams or carefully plotted exegetical commentary.
\end{abstract}

\section{Introduction}

To a certain extent, we are still catching up to the multiplicity and variety of early modern autobiographical writings by women. This is particularly true in the case of religious writings: even though research in this area has multiplied over the last two decades, and especially in the first years of the twenty-first century, the challenges posed by these texts keep compelling 
us to reassess our preconceptions of what women's writing is, and of what it has been over history. No doubt this is the result of the enormous variety of these texts: along with the general impulse given to writing by the spread of Protestantism, there were multiple and often incompatible traditions of belief that developed in Britain during the sixteenth and seventeenth centuries; the very act of writing had different meanings and connotations in each of these traditions, and this applies as well to the concept of "self" expressed in autobiographical texts. The massive extension and dissemination of prophetic utterances that is intimately characteristic of the climate of dissent in seventeenth-century England compels us to review the interrelation between contemporary politics, religion and the public sphere. Orianne Smith, in her study of the female prophetic tradition, contends that "these women and many others believed that they were writing and prophesying during a critical juncture in English history - a point in which sacred and secular history converged - and this shared belief gave their prophetic discourse a political edge and provided them with an audience willing to listen to their interpretations of God's will'. (Smith, 2004: 87) At the same time, drawing on the Old Testament prophetic tradition, the act of prophesising necessarily bears implicit a political pronouncement of some sort. According to the Oxford Companion to the Bible (1993: 621), "prophecy in Israel represents the true prophet as the agent and defender of Yahweh in opposition both to religious apostasy and syncretism and to the authority of kings when these failed to uphold the cause of Yahweh or flouted his moral demands". This definition suggests that the political substance of prophetic writing is an imperative of the genre, and that both divine inspiration and political counsel to ruling authorities are embedded in the prophetic text.

This article aims at contributing to the study of seventeenth-century English prophetic writings by focusing on the rhetorical strategies used by women prophets and the persuasive nature of prophetic speech, at a juncture where political and religious events allowed women's irruption into the public space. This study consists of the following parts: first, I will be concerned with the background of women's prophetic writing in seventeenth-century England, and the way women's zeal towards appropriating a wider parcel of the public sphere in oral and in written form took them to modify traditional notions of femininity; second, I will move on to analyse Elinor Channel's case, illustrating the fact that it was not so much the material content of the divine message, but the capacity to act upon it in public profusion what empowered women towards a greater notion of themselves as individuals; third, taking Channel's case as an example, I will illustrate the fact that that dense biblical allusions and the "leadership of scripture" can be appropriated to create personalised and persuasive prophetic messages. The conclusions will bring this study to an end.

\section{The background of prophecy as a foundational moment}

As readers of early modern literature, we cannot forget that for women the simple act of writing and speaking in public was fraught with major difficulties and dangers. The Pauline injunction that women should not minister, as dictated by Paul in his first Letter to the Corinthians, ${ }^{1}$ had long been an issue of debate among defenders and detractors of women 
public speaking, and was frequently invoked in the intellectually-minded Querelle de Femmes both in France and in England. But women dissenters, by dint of their prophetic roles, learned to go beyond the boundaries of religious propriety by speaking in public locations separate from churches and/or sectarian gatherings. The Pauline injunction and religious authorities could forbid them to talk in the established churches, but they could not prevent them from preaching in the streets of London, in taverns and in other public hotspots. This flourishing of public speaking, in both its spatial and its printed manifestations, contributed in a relevant manner to the creation of an independent public opinion occupying a visible public sphere. As several scholars have noted (Feroli, Wiseman, Hinds, Coles), what preoccupied political and religious authorities was not so much the act of women as speakers, but their capacity to alter public order and influence the masses with messages that were inimical to mainstream governmental policy.

As Patricia Crawford demonstrates in her listing of seventeenth-century women's published writings, more than half of publications by women during the period could be classified as prophetic. Scholars agree in labelling this type of writing as "prophetic" and most of them, like Teresa Feroli (2006: 19), suggest that "the women prophets' publishing record represents a major milestone in women's literary history"; namely, well over half the texts published by women between 1649 and 1688 were prophecies. Further studies indicate that the prophetesses who published in the revolutionary period (1630-1660) began a trend that continued through the end of the century. The Restoration did not bring about a significant decline in the numbers of women's published works, but rather the stabilization of their literary production; this fact alone has led many experts (notably Feroli, Ezell, Mack, Purkiss and Hobby) to stress the pivotal position of prophetesses within the history of women's writing in England.

Before adjusting our perspective to scrutinise the lives and motivations of these visionary women writers, we need to ascertain what kind of writing we are defining as 'prophecy'. Most scholars who have studied women's prophecy in seventeenth-century England agree in considering it, in broad terms, a direct communication from God or an inspired reading of the Bible. Diane Purkiss (1992: 139) has defined it more specifically as "any utterance produced by God through human agency". For Teresa Feroli, women prophetic utterance distinguishes itself from other spiritual or visionary kind of writing in that prophetesses in the seventeenth century sought to justify a role for women as political activists; whereas for Antonia Fraser (2005: 304), prophetic writing "might challenge accepted notions concerning religion and society but the prophetess did not necessarily in her own person challenge the accepted order". In every approach, the function of a prophetess is never understood as one of 'foretelling the future' - although in some instances that could be the case - but as facilitator of God's will through a human being.

In order to define better the modalities of early modern prophecies, it is necessary to take into account the essential characteristics of Biblical prophecy. A keynote feature of the prophetic books found in the Old Testament is that they speak of the present as well as the future: biblical prophets often tie the two together, suggesting that the future is the result of present mischief and that disaster can be avoided through a change in people's behaviour. Often, Old Testament prophets advocate a particular way of living or even an ethical position, 
although that position can vary from prophet to prophet and to their specific social circumstances. Among these classical prophets, we find oracles denouncing the sin and apostasy of Israel and Judah in books such as Isaiah, Jeremiah, Amos, and Hosea, and they include predictions of national disasters usually at the hands of foreign powers; they usually attribute this impending disaster to the sins of the community they speak to, urging the faithful (and the unfaithful) to repent before it is too late.

John Barton suggests that behind the common elements and patterns of prophetic utterance from the old Jewish prophets to early modernity there is more artifice in the prophetic message than appears at first sight. Since the purpose of the biblical prophets was to give an account of the facts of history (with their ambiguous moral and religious implications) so as to convince people that the hand of God was behind them, we can conclude that the long tradition of prophetic rhetoric from the Old Testament to the seventeenth century is designed to bring human history and ethical behaviour under the design of the divine will. As Barton (1990: 52) remarks:

The chief concern of the prophets is theodicy, the justification of God's ways with his world. In the interests of a coherent theodicy, great rhetorical skill is needed to be employed. Even if we can hardly avoid questioning the prophets' theology, we are bound to admire their literary talent.

Biblical prophetic books by Luke, Daniel, Matthew or the Book of Revelation were widely read and appreciated by dissenting groups of all denominations because these reinforced the notion that "As he spake by the mouth of his holy prophets, which have been since the world began" (Luke, 1:70). The statement justifies the adoption of a prophetic role as an activity sponsored by the Bible, and prophetic utterances in turn become highly significant for justifying one's writing and the author's relationship with religious discourse.

A similar pattern is to be found in women prophetic utterances from the seventeenth century. They echo God's concerns with the contemporary state of affairs and they display rhetorical skills which go beyond the written and the uttered word to be re-enacted in public. On the one hand of the spectrum, post-structuralist scholars like Christina Berg and Philippa Berry (1981: 38) focus almost exclusively on the rhetorical strategies employed by prophetesses, considering that they "represented their own sexuality within a discursive medium where an explicitly political content was subsumed within a highly personalized mode of expression". However, most scholars consider, with various degrees of emphasis, that the rhetorical power of prophetic speech in the seventeenth century goes beyond the content of the words themselves and is the interaction between the Biblical message and its various appropriations and interpretations by female prophets what transforms prophetic writing into a rich locus of study. Elaine Hobby (2002:269) reminds us of the inescapable fact that the role of a prophet gave a woman access to an audience for her views, and is precisely this more neglected aspect of prophetic speech - the exchanges between the prophet and her public medium - what the present article is interested in highlighting. Even when we readers in the twenty-first century disagree with the content of those prophetic messages, we cannot deny their narrative craft and their public impact and influence.

Due to the revolutionary and millenarianist climate of the mid-seventeenth century, the Bible gained prominence as divine justification for the words of God, away from any human 
agent or Episcopal intervention. Prophetesses were not regarded as mediums who meddled with God's will and speech, but rather as mere recipients of his word, precisely because the recitations of these women relied very heavily on Biblical passages, citations and allusions. Women were particularly apt for adopting this prophetic role, since their biological construct as 'vessels' and 'recipients', as well as their social roles enabled them to act as perfect channels for God's speech. Phyllis Mack expands and qualifies this view by remarking that characterising the female 'visionary' as an empty vessel cannot be easily termed as 'misogyny'. In fact, she reminds us that:

\begin{abstract}
The defects of rationality and the attuned intuition of visionary women were actually viewed with respect, even envy, by those philosophers who felt alienated from God by their compulsive, prideful reliance on the power of their own reason. Indeed, in this respect all women had a clear spiritual advantage over men, for the static resulting from their weak and intermittent surges of intellectual energy were less likely to interfere with their capacity to act as receptors for the divine". (Mack, 1994: 33)
\end{abstract}

This emotional quality of women which makes them receptive and intuitive channels is appropriate for the expression of spiritual values. So prophetic writing may thus appear as intimately related with the feminine because it requires from the prophet "an emptiness", a passivity, and an emotionality necessary to prophesise. We find an eloquent example of the suitability of prophetic speech for women (and its wider social acceptance compared to other forms of female public speech like preaching or pamphleteering) when in 1654 an Independent church congregation debated whether the average man had a dominion over prophetesses such as he had over 'all widows and maids that are not prophetesses". They relied upon St Paul's remark in his First Epistle to the Corinthians that 'every woman that prayeth of prophesieth with her head uncovered dishonoureth her head'; it was understood that, since St Paul did not forbid prophetesses and even seemed to tolerate them if they covered their heads, then "a woman (maid, wife of widow) being a prophetess may speak, prophesy, pray with a veil. Others may not". 2

For a long time, seventeenth-century prophetic writings were excluded from literary consideration because they were regarded as too inaccessible, political, religious writing, and as a sub product of their own times. A number of scholars on seventeenth-century literature even remarked that these materials might hold political and historical interest, but had very little to offer in terms of literary value; the Australian feminist critic Germaine Greer stated at one point that "the women who tried to write poetry in the century of Donne, Milton and Dryden as untrained, ill-equipped, isolated and vulnerable" (Greer, 1988: 1). At the same time, the obscurity of prophetic language can also be viewed as an imperative of the genre. According to Fausset's Bible Dictionary:

The absence of greater clearness in the prophets is due to God's purpose to give light enough to guide the willing, to leave darkness enough to confound the willfully blind. Hence the prophecy is not dependent for its interpretation on the prophet. [...] The obscurity, in some parts, of prophecies of which other parts have been plainly fulfilled is designed to exercise our faith, the obscure parts yet awaiting their exhaustive fulfillment. (Fausset, 1979:544) 
The dense Biblical allusions and the complex interweaving of narrative voices may have acted as a deterrent to the literary appreciation of these women writers, but thanks to the recent work of scholars such as Margaret Ezell, Hilary Hinds, Helen Wilcox, Jennifer Richards, and Teresa Feroli, prophetic texts by women have been analysed in detail and put against the backdrop of the English literary canon at large. This critical assessment now agrees on the fact that prophecy allowed "a process of constructing and articulating an identity through the act of writing, in which self-other relations are constantly renegotiated" (Ostovich, 2004: 134), and it is precisely this shaping of an identity, moving back and forth from self-affirmation to self-effacement, what characterizes prophetic texts not only within the canon of English literature, but also in the genesis of a proto novelistic discourse ${ }^{3}$ and even of an early awareness of gendered-cultural distinctions. As Teresa Feroli (2006: 15) puts it:

Women prophets of the English Revolution inaugurate an early phase in the rise of modern feminist consciousness. Although the women prophets are not feminists in the sense that they do not intervene in the political sphere solely to improve the lives of women, they do represent an important moment in the history of feminism because they seek to justify a role for women as political activists.

For Feroli, prophecy projects a female authority both inside and outside the written word which evolves from being an adjunct of patriarchy to an attribute of female sexuality, and this legitimizes prophecy as a mode of expression in writing with a distinctive literary quality: that of conflating the personal, the political, the religious and the feminine identities, all of them intermingled in a discourse which is profoundly metaphoric, persuasive and distinctive in its graphic and emotional connotations.

In this regard, religion and politics do not have to be viewed as 'obstacles' to women's free creative faculties, but must rather be taken as cultural definers in their social milieu. The religious discourse permeated politics, culture, and science throughout the seventeenth century. The civil wars of the 1640s, the execution of Charles I in 1649, Cromwell's Protectorate or the restoration of Charles II to the throne in 1660 are political and historical events which articulated themselves through the language of religion. The king was head of state but also 'defender of the faith' leading the Church of England through divine mandate; in his inaugural speech of the Barebones Parliament in 1653, Oliver Cromwell quoted Daniel and Revelation quite extensively, and was hailed by some members as the "second Moses". Hilary Hinds (1996: 7) complements this view by observing that "it is confusing, not to say profoundly misleading, to try to separate and compartmentalise the discourses of religion and politics; there were one and the same". The main issues at stake revolved around God's plan for the world: what kind of society was closest to his will? Was it strictly hierarchical or one in which only distinctions of a spiritual nature mattered? The multiple factions within the political elite gave an answer to these questions which was markedly different from that of the increasingly powerful Puritan groupings, or of the grassroots and 'dissenter' movements proliferating in the middle years of the seventeenth century. Prophetic speech found a fertile ground in the spreading out of these 'independent' sects, such as the Baptists, the Fifth Monarchists, the Levellers, the Familists, the Independentists and the Quakers, which flourished in the relatively tolerant social environment of the Revolution, espousing its own 
particular religious and political agendas. ${ }^{4}$ One of their major common denominators was their insistence on the fact that the state powers - including the monarchy - should not have a say in ecclesiastical matters, as well as their stress on the spiritual equality of all human beings. Some of these movements, particularly the Fifth Monarchists, had their origins in the millenarian ideas circulating in the 1640s predicting the second coming of Christ and the establishment of the New Jerusalem on earth (specifically, in England). The millenarian fervour stressed the role of prophecy, the reading and interpreting of the Scriptures as a guide to understanding present and future events, and defended (even as a basis for political action and regicide) a literal interpretation of the biblical prophecies or Daniel and Revelation. ${ }^{5}$ Due to the reformed spirit which animated them, many of these sects paid special attention to practices such as self-examination through reading the Bible, thinking, and acting upon one's own convictions, thus reaching new possibilities of self-awareness and affirmation. According to Feroli (2006: 22), "the sects proved particularly conducive to female advancement because they emphasized the spiritual equality of the sexes. This belief, together with the sect's privileging of the individual's direct relationship with God, meant that women were as responsible as men for their own salvation". They also appealed to the Protestant principle of the spiritual equality of the sexes in the sight of God, which made individuals responsible for their own individual salvation and that of the community they belonged to.

Because prophetic discourse figured prominently in the politics of the English Revolution, women's pronouncements on matters of national importance were taken more or less seriously by the ruling authorities. This did not imply that government officials often consulted women prophets in times of crisis. Typically, seventeenth-century governing authorities imprisoned women prophets because they feared their words were being heeded by potentially disruptive segments of society.

\section{The case of Elinor Channel: an interrogation}

In order to evaluate the practical consequences and implications of prophesising by women it is necessary to pay attention to the rhetorical and material strategies that give prophecy its weight and personality as a genre. When Elinor Channel in her A Message from God by a Dumb Woman (1653) begins her call to the Lord Protector to invite Charles II to come back as king of England, she begins by explaining the surprising events that befell her. One night she "had a blow given upon her" that "from that day to this, "she [Elinor, the "petitioner"] could think of no evil. And the thoughts of your petitioner's heart were so directed, that she was given to understand how that the Spirit of the Lord had called her" [italics in the original source] (Channel, 1653: 3). After this revelation Channel, who was married to a "very poor man and hath many small children", encountered the opposition of her husband, who did not want her to travel alone to London from her native Surrey. This marital clash was resolved when all of a sudden "her sleep went from her and she was speechless". Elinor's husband interprets her severe condition as a divine sign, and consents on her trip to London. She is lost, exhausted and verbally abused when she reaches the capital because of her "dumb state". Eventually she does not manage to get a royal audience, but wanders the streets of London "to 
see if she could get anybody to take it from her mouth and publish it in print". Providence wants it that Elinor's presence is noticed by a relatively well-known male prophet, Arise Evans, who upon her wishes and impressed by the transcendence of her dispatch, decides to publish her "words of advice" to Cromwell; with this, she hopes that her message "will not onely be accepted of you, but will be also effected by you" (Channel, 1654: 9).

Arise Evans makes it clear in the cover page that the whole text is "published according to Elinor Channel's desire", although he stamps some occasional glosses in the margins, as when she writes: "She is to say to you, Sir you have taken upon you to be a Protector of your Lords Vine-yard, but he requireth that you should make the Hedges and the Walls of it, which is Peace \& Love, and the true Gospel", at which Arise Evans glosses "By the True Gospel she meaneth that worship we had once" (Channel and Evans, 1653: 10). This clarifying remark on the part of the publisher reveals that Elinor acts as a sort of exegete herself, too, which reminds us of the fact that, according to Feroli (2006: 26) "women prophets inherited a second radical Protestant tradition: the exegetical writings of major scriptural scholars on Revelation and Daniel". Therefore, Elinor's text is both inspired by divine utterance and collated by her own authorial voice, no matter how much the latter is disguised under the 'Petitioner'.

Channel's work exemplifies much of the common ground to be found in prophetic writings by women: a sudden and often violent divine revelation - the opposition of family and friends - a powerful message of religious and/or political nature. But $A$ Message from God is telling for other less obvious features: the prophetess is as interested to render a political-religious message as she is to be noticed as a voice and a presence filling in a public space. Channel's 'advice' is written in the third person singular, not in the first person as in autobiographical form. Scholars usually interpret this blurring of authorial presence as an act of shyness or caution on the writers' part, but it is equally true that using a semi-omniscient narrator creates a much more powerful narrative effect. Channel's advice is not read - even by her contemporary readers - as an informative piece or as a fanatical petition devoid of dramatic tension. It can be read as a story in its own right, with a protagonist (Channel), a mission, an obstacle, and a saviour (Evans). The fact that she is left dumb is not exempt of Biblical connotations, ${ }^{6}$ and Evans himself adopts the role of a Biblical scholar who undertakes an exegesis of the word of God uttered though Elinor's petition. She is a servant and an instrument of God, who turns her dumb so that He can pronounce his solemn advice, while Evans becomes in truth instrumental to Elinor, carrying out her will of publicizing her petition and undertaking an exegesis of the text. Her message is so important that it deserves an exegesis, as in the Scriptures.

Note that Elinor insists on making known her message by the medium of print, since she has not been granted a royal audience. This gesture reveals an awareness of the relevance of the printing press as a tool for widespread communication as well as a willingness to speak through it. If Elinor's pronouncement had been a product of her intellect and imagination only, and had not been perceived, by herself and by others, to be endorsed by God, she would probably never have been published.

This line of argumentation does not entail, of course, that Elinor and other prophetesses were impostors who manipulated an alleged divine message to be on the spotlight. The 
reading of an ample variety of these texts leaves no doubt women were genuine in their beliefs and many of them took personal risks in delivering them. But it also raises a number of questions on the often unnoticed fact that many women found a discourse which empowered them in the first place to occupy a parcel of public representation and to be more visible, even prominent, in it. One aspect which commands the attention of a careful reader of Elinor's text and other similar writings by her female contemporaries is the richness in layers of meanings and rhetorical strategies employed by women prophets. They can not be easily dismissed as the ravings of religious fanatics. By paying attention to a number of rhetorical strategies and gesticulations, this thesis will defend that it was not so much the specific content of their religious and political messages what prompted women and empowered them to take on a public stance, but that, on the contrary, it was precisely the possibility of adopting a prophetic role which gave them a relative safe venue from which to speak. Prophecy invested them with Biblical tradition so as to make their invasion of the public space less offensive for civic order and provided them with a moral authority and a vivid discourse to catch their audiences' attention.

\section{Lady Eleanor Davies and the persuasion of anagrams}

Another case in point is Lady Eleanor Davies's accurate prediction of the death of Charles's chief advisor, the Duke of Buckingham, which earned her popular acclaim and deeply troubled the King. He subsequently took a personal interest in seeing her imprisoned in 1633 after she illegally published and distributed some of her treatises.

Lady Eleanor Davies (1590-1652) was born to George Touchet, Baron Audeley, and his wife Lucy. Little is known about the conditions of Lady Eleanor's upbringing and education. Her biographer, Esther Cope, appeals to the content of Lady Eleanor's writings to speculate that she may have been trained in Latin in addition to exposure to classical and modern authors. In 1609, she married the poet and prominent barrister, Sir John Davies, to whom she bore three children.

Her prophetic career began in 1625 with the publication of $A$ Warning to the Dragon and all his Angels. An exegetical treatise on the prophecies of Daniel, Warning predicted that "the Day of Judgement" would occur "nineteene yeares and a halfe" from $28^{\text {th }}$ July 1625 . In Warning, Lady Eleanor also introduced the anagram "Eleanor Audeley, Reveale O Daniel" that would appear as her signature in many of her treatises and through which she attempted to assert that her family name possessed hidden properties which linked her to the prophet Daniel.

Concerned with his own career, her husband discouraged Lady Eleanor and burned one of her early treatises. She responded by telling Sir John "within three years to expect the mortal blow", and he died shortly thereafter in 1626 . When her second husband, the soldier Sir Archibald Douglas burned her prophetic writings, she cryptically predicted that "worse than death should befall" him. By her account, this prediction was fulfilled when, during church services, Sir Archibald was "strooken bereft of his senses, in stead of speech made a noice like a Brute creature". 
In 1633, Lady Eleanor travelled to Amsterdam to find a printer willing to produce her treatises. Once she returned to England and began to distribute her newly printed tracts, Archbishop Laud ordered them burned. Beyond destroying her books, Laud oversaw her trial before the Commission for Causes Ecclesiastical at which the judges determined that her writings "much unbeseemed her Sex" and she was sentenced to two years in prison.

In terms of her literary output, Lady Eleanor's most productive years came between 1641 and 1652 when she published 66 of her 69 treatises. Although the easing of censorship restrictions in this period clearly enabled her to publish with greater freedom, she continued to encounter official opposition and found herself in and out of jail in the years between 1646 and 1651 .

By contributing to the revolutionary politics of their time, Davies and other women visionaries exceeded the boundaries of traditional female social roles. For many of their contemporaries, the idea that a woman would undertake to speak on weighty theological and political matters was nothing short of blasphemous. Such was the view of the clergymen who tried Lady Eleanor. They denounced her for presuming to explicate the prophecies of Daniel: "she took upon her (which much unbeseemed her Sex) not only to interpret the Scriptures, and withal the most intricate and hard places of the Prophet Daniel, but also to be a Prophetess, falsely pretending to have received certain Revelations from God". As the documents from Lady Eleanor's trial suggest, many of the women visionaries' peers deemed their public speaking and writing an assault on male prerogative. Erica Longfellow (2004: 49) says that "the confusion between male and female, the believer and the Church, opens up possibilities for early modern writers to negotiate gendered power relations whether real or metaphorical", and this constant back and forth from gender concerns to religion and politics seems to be a particular feature of Lady Eleanor Davies. In 1625, when she was in her mid-thirties, according to her own account she received a revelation while lying in bed at home at Englefield Manor: "Nineteen and a half years to the Judgement and you as the Meek Virgin". Sir John Davies died the next year, but since Lady Eleanor - who shared a contemporary preoccupation with anagrams - made of her husband's name DAVID IUDAS we cannot say she regretted his demise. Sir John's particular betrayal, as we know, was described by Lady Eleanor: her first book was "sacrificed" by her husband, to which she responded with a prophecy of "a mortal blow".

\section{The Word of God}

An interesting example of the exchanges between female self and religious and political authority can be found in The Word of God (1644), where Lady Eleanor Davies recounts the execution of her brother, the notorious Earl of Castlehaven - who was executed for the crimes of marital rape and sodomy - interpreting his treatment at the hands of his accusers by referring to the New Testament parable of the talents (Luke, 19). Written in her customary and somewhat hyperbolic style, the text features abundant biblical and personal references. The Word of God to the City of London is a complex work of what may first appear to be obscure biblical interpretation and prophetic hieratism. To best appreciate it, the reader needs to 
interpret its exegesis of Luke 19, Jesus's "parable of the talents", on several levels related to Davies's biography and times. The parable, which also appears in the gospel of Matthew, tells the story of three stewards entrusted with investment money by their wealthy lord. Two invest wisely and are rewarded according to their earnings. The third buries the money, thereby realising no return, and is in consequence punished.

Davies uses the parable as a springboard both to present her version of the execution of her brother, the Earl of Castlehaven, and to connect this traumatic event to the recent political downfall of the man she felt was responsible for the present disorders in church and state in England, namely, Archbishop of Canterbury William Laud. Throughout this short tract, Davies quotes biblical texts and deploys abundant pieces of scriptural language, as she moves back and forth between the narrative of her brother's execution, references to Laud's imprisonment, and the story enclosed in the parable.

The imprisonment of Laud in 1644 had a special significance for Davies as she wrote The Word of God. Davies viewed Laud much the same way puritans, old-style Calvinists and Parliament viewed him: as the tyrannical power behind the unlawful re-sacralizing of the English church of the 1630s. Laud's trial inspired Davies to retell the story of her brother, the notorious Mervyn, Lord Audley. In the domestic context, then, the scriptural basis for The Word of God should be read taking into account the circumstances leading to Castlehaven's shameful death. While she defends his aristocratic honour, Davies admits her brother's execution was inevitable, given his mismanagement of an "unruly household".

And now Sirs you of this Honourable Citie as you have heard these: Shall adde a word of His Majesties Atturney generall that day after they had heard the examination (falen to a low ebb of what was expected) saying my Lord. You see this odious crime, and therefore you must be curious you admit of no Mittigation, who came short of this first promise. That His Majesties intent was like God to shew mercy, who from fifty did come down to ten when he interceeded for Sodom. (Davies, 1644)

It is with this reference to domestic disorder, borrowing the image from Sodom and Gomorra from the King James' Bible that Davies makes a logical connection between her brother's execution and more immediate religious and political events. England was involved in civil wars of religion between parliament and king, and contemporary observers would have felt as if their world had been 'turned upside down'. Political and social organisation had long been based on concepts such as "family" and "patriarchy", and Davies must have considered the disordered Audley household to be a microcosm of Charles I's unruly kingdom in the 1640s. Ironically, the chaotic atmosphere that Davies deplored was a boon to her efforts: with governmental censorship suspended and public fears on the rise, apocalyptic tracts like The Word of God flourished in the Civil War era.

\section{Tobit's Book}

Often, Lady Eleanor's prophecies are difficult to determine: her style is elliptical, condensed, highly metaphorical and ripe with vivid imagery which seems to excite the senses of the 
reader. According to Elaine Hobby (2002: 266), these stylistic features of Davies have prompted some commentators to read her texts through the lenses of "French feminism theories, and to see their passionate and anarchic language as a kind of eruption of the semiotic chora through the constraints of the signifying chain". Such interpretation would see the ecstatic woman prophet as a representative figure, whose words and punishments are typical of the social situation of most women at that time. However, Hobby discourages this French-based psychoanalytic model, stating that Lady Eleanor's pamphlets do not really fit in it because variations between copies and editions of these prophecies demonstrate clear planning and deliberate purpose, what in turn shows that Davies was careful in her writing style. In this regard, Hobby hesitates over the fact that Lady Eleanor's prophecies can be regarded as typical of their age, another factor being that her high social rank allowed her to pay for her pamphlet's printing and this granted her a degree of freedom in her authorship (leaving aside the prosecutions against her).

One interesting aspect of Lady Eleanor's prophetic production and of her writing style is her commentary of the Book of Tobias ${ }^{7}$ entitled Tobit's Book (1652). Lady Eleanor's singularity derives not only from her decision to address this Biblical piece but also from her approach to it: she reads this apocryphal biblical book as an apocalyptic text that prefigures Christ's triumphant return at the end of time. Tobit's Book is an excellent example of the way that Lady Eleanor wove biblical allusions together to create a prose style in which key themes, in kaleidoscopic fashion, continuously reappear, emerging in new formations from the colourful elements that directly precede them.

Tobit's Book is the penultimate treatise of Lady Eleanor's canon, and it examines the apocryphal Book of Tobit in order to encourage readers to recognize that suffering is always followed by redemption. Although her contemporaries may feel they belong to a condemned generation (as Lady Eleanor certainly believes they do), God will come to them in the magnificence of the "New Jerusalem". Lady Eleanor's Tobit's Book adds an apocalyptic twist to the original biblical Tobit.

His Grave whenas prepared abroad and at home both: their son by whom she conceived (as it were) returned into a New World: such a change closed with Father Tobias Trumpets Alarm or Prayer: by the Angel preferred, withal pointing to his close Imprisonment in the Whales womb, three days in Travel of him: heard whose cry out of the Deep, who acknowledges brings up from Hell. And Hell and the Grave, one and the same word Gehenna expressing both as in that similitude from unlikeness. (Davies, 1652)

In this and other excerpts we see that Davies is particularly interested in the accounts of how Tobias, following the advice of the Angel Raphael, uses the fish he captures in the Tigris River to cure first his bride Sarah of spirit possession and second his father Tobit of blindness. Lady Eleanor understood Tobit as an account of God's mercy on the suffering but she also sees in its narrative of divine redemption a type (or prefiguring) of Christ's triumphant return at the end of time:

"[...] And in Adam as all died, so in Christ all made alive". Cor: 15. "O the depth of the wisdom and knowledge of God". By the Ancients Origin, Tertullian and others: no question made thereof 
"with whom all things possible", but to be implacable absolutely. (Davies, 1652)

Here we read of her reference to the Church Fathers as supporting or complementing her commentary of Corinthians 15 , which reinforces once again her thick and particular use of Biblical references to compose a collage of voices and meanings which seem to be at the same level of authority. This multi-vocality in Bakhtinean terms not only speaks of Davies' deep knowledge of the Bible but also points at a stylistic dynamism: that of a female writer who tries to show her command of a multiplicity of voices in order to produce a style of her own. In this regard, we could argue that there is a clear sense of a religious and even a literary identity which strives to make her presence known, which is exactly what Mack, among other scholars, suggests:

Many women had both the spiritual and the intellectual capacity to contribute to the religious and the political discourse that dominated the Civil War period, and clearly, their intention was not to subvert all traditional morality or destroy every vestige of established authority. (Mack, 1992:104)

The fact that Lady Eleanor produces in 1652 a meditation on the Book of Tobit is significant because hers is the only commentary on Tobit published in the period. Tobit is one of the apocryphal books of the Bible, and as such it was not considered one of the canonical texts of scripture. And it is a well-known fact that, over the course of the Protestant Reformation both on the Continent and in England, the apocrypha came to be held in increasingly low esteem.

\section{By way of conclusion: prophetic speech in the public arena}

The analyses carried out in this article invite us to consider the fact that being heard, published and paid attention to was a rhetorical persuasive strategy for its own sake, and as important for women prophets as the message itself. Davies' choice of Biblical texts as a rhetorical base, and her particular exegesis, is another point in the case for placing her in a specific location in the early modern women's canon: that of the conscientious prophet writer who is well versed in the Bible and eager to absorb and participate in the religious and political events of her time. Her writing style is denser than that of other contemporary prophetesses, such as Elinor Channel, the Fifth Monarchist Anna Trapnel or the Quaker Katherine Evans, in the sense that we do not find an actual negotiation of identities in the text between the author and the social constructs of her message; in Davies we see a distinctive leadership of the Scripture, which imbricates her treatises in such a way that the text itself, very much devoid of personal or passing commentary, becomes a source of moral, spiritual and political authority. In Channel, though, the appropriation of a public space in oral and printed form becomes for her a matter of national urgency, as well as the main rhetorical and material argument in persuading the audience of the significance of her prophetic speech.

As we have seen in our close reading of the case texts, their seeming dichotomy of voices does not imply an open or (in Bakhtinian terms) a polyphonic perspective: what we have here is multi-vocality, but not heteroglossia. It is above all the voice of the Spirit animating the prophetic speech what is asserted and recognised in the texts, and it is that voice which is 
presented (both thematically and typographically) as having a pre-eminent authority over all the others. The identity of Eleanor Davies and many other prophetesses of her time is created dynamically in the text: first, through the constant dialectic exchange between the prophet voice and those of the male authorities that she opposes, and secondly (and even more importantly), through her personal, close interaction with the voice of the Spirit. Identity is thus created here both through defence of a religious position and through an intimate sense of exchange with the voice of God, which in the text is presented as speaking to the prophet in the accents of the Bible. As a consequence, the prophetess's individual voice is deeply embedded in the language and the structures of Holy Scripture, and empowers her to occupy a public space.

Determining the extent to which this strong resistance to gender differentiation is a general feature of early women prophetic writing is beyond the purpose of the present article. It will be sufficient, for the moment, to conclude that the feature we may be tempted to recognise as most "modern" in the writings of Eleanor Davies, Elinor Channel and many other prophetesses appears to be, in the final analysis, one which is strongly imbricated in their religious beliefs so as to forge a persuasive discourse which is then appropriated. Kimberly Anne Cole (2008: 7) has it right when she writes that "in the struggle against oppression, the terms of religion, properly negotiated, were among the most effective tools that women could employ".

Through the analysis and careful reading of representative texts by several English women prophets, this article aims at further cementing prophetic writing as a particularly distinctive genre of women writing in the seventeenth century. The prophetic text, more than political pamphleteering, goes a step beyond the mere exposure of the 'I' in the written page: it presents and negotiates multiple notions of the self which are intimately related with God, and with oneself. Thus prophetic writing is not only a relevant field of study because it allowed women to participate in the public sphere in relatively large numbers or because it allowed them a venue to write; but more importantly, because it helped them create an identity in the act of speaking and writing. Our role as readers of early modern literature is to be able to appreciate the cultural distance between us and these texts while acknowledging the unique strength and vitality with which they continue to speak to us today.

\section{Notes}

1. "Let your women keep silence in the churches: for it is not permitted unto them to speak; but they are commanded to be under obedience, as also saith the law. And if they will learn anything, let them ask their husbands at home: for it is a shame for women to speak in the church". (Paul's first Letter to the Corinthians, verses 34 and 35)

2. Antonia Fraser in The Weaker Vessel retells this anecdote found in a Puritan Congregation Minute Book, 1654, Rawlinson MSS, D. 828, fo. 30/32.

3. Typically, the Russian critic Mikhail Bakhtin (1995) refers to the myriad of texts in the early modern period as constituting an early phase in the emergence of the novel as a genre. Gallagher and Greenblatt (2000) echo similar thoughts about the importance of proto novelistic texts, since these cannot be understood outside the very specific context of their production. 
4. For a detailed study of radical sects and ideas in the seventeenth-century, see Hill (1991) and Morton and Smith (2002).

5. Radical Protestant tradition fed on exegetical readings of Daniel and Revelation made by scholars, mainly by John Bale in 1550s. Bale argued in The Image of Bothe Churches that the Book of Revelation told the history of the Protestant church opposing the corruption of Catholic powers.

6. Allusions to dumbness are abundant in the Bible, and they mostly refer to the act of human speech been controlled by God, as in Psalm 39:9: "I have become dumb, I do not open my mouth, Because it is Thou who hast done it."

7. A book of scripture that is part of the Catholic and the Orthodox Biblical canon, pronounced canonical by the Council of Carthage of 397 and confirmed for Roman Catholics by the Council of Trent (1546).

\section{References}

Bakhtin, Mikhail (1995): Rabelais and his World. Bloomington: Indiana University Press.

Barton, John (1990): "History and Rhetoric in the Prophets". In M. Warner, ed., The Bible as a Rhetoric: Studies in Biblical Persuasion and Credibility. London: Routledge, 51-64.

Berg, Christina and Phillipa Berry (1981): "Spiritual Whoredom: An Essay on Female Prophets in the Seventeenth Century". In F. Baker, ed., Literature and Power in the Seventeenth Century. Colchester: University of Essex Press, 37-54.

Channel, Elinor (1653): A Message from God, By a Dumb Woman to His Highness the Lord Protector. London: Arise Evans.

Cope, Esther (1993): Handmade of the Holy Spirit: Dame Eleanor Davies, Never Soe Mad a Ladie. Michigan: University of Michigan Press.

. (ed.) (1995): Prophetic Writings of Lady Eleanor Davies. London: Oxford University Press.

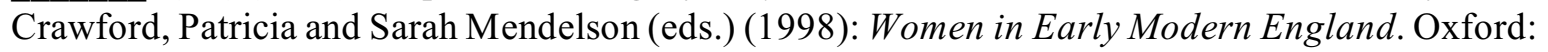
Clarendon Press.

Feroli, Teresa (2006): Political Speaking Justified: Women Prophets and the English Revolution. Newark: University of Delaware Press.

Fraser, Antonia (2005): The Weaker Vessel: Woman's Lot in Seventeenth-century England., 3rd ed. London: Arrow Books.

Gallagher, Catherine and Stephen Greenblatt (2000): Practicing New Historicism. Chicago: Chicago University Press.

Greer, Germaine and Jeslyn Medoff (eds.) (1988): Kissing the Rod: An Anthology of SeventeenthCentury Women's Verse. London: Virago.

Hinds, Hillary (1996): God's Englishwomen: Seventeenth-Century Radical Sectarian Writing and Feminist Criticism. Manchester: Manchester University Press.

Hill, Christopher (1991): The World Turned Upside Down. London: Penguin.

Hobby, Elaine (2002): "Prophecy". In A. Pacheco, ed., A Companion to Early Modern Women's Writing. Oxford: Blackwell Publishers, 264-281.

Longfellow, Erica (2004): Women and Religious Writing in Early Modern England. London: Cambridge University Press.

Malcomson, Cristina and Miholo Suzuki (2002): Debating Gender in Early Modern England 15001700. New York: Palgrave.

Mack, Phyllis (1998): "In a female voice: Preaching and Politics in Eighteenth Century British Quakerism”. In B. M. Kienzle and P. J. Walker, eds., Women Preachers and Prophets through 
two Millennia of Christianity. Berkeley: California University Press, 130-155.

Metzger, Bruce and Michael Coogan (eds.) (1993): The Oxford Companion to the Bible. Oxford: Oxford University Press.

Morton, Timothy and Nigel Smith (eds.) (2002). Radicalism in British Literary Culture 1650-1830. Cambridge: Cambridge University Press.

Ostovich, Helen (2004): Reading Early Modern Women. New York: Routledge.

Purkiss, Diane (1992): "Producing the voice, consuming the body: Women prophets of the seventeenth century". In I. Grundy and S. Wiseman, eds., Women, Writing, History 1640-1740. Athens: University of Georgia Press, 139-158.

Smith, Oriane (2004): "Unlearned and ill-qualified Pokers into Prophecy: Hester Lynch Piozzi and the Female Prophetic Tradition”. Eighteenth-Century Life 28 (2): 87-112.

Trill, Suzanne, Kate Chedgzov and Melanie Osborne (eds.) (1997): Lay by your Needles, Ladies, Take the Pen: Writing Women in England 1500-1700. New York: Hodder Arnold. 